Abditani : Jurnal Pengabdian Masyarakat 2 (2) 66-66

e-ISSN : 2622-4690

p-ISSN : 2622-4682

\title{
SOSIALISASI DAN APLIKASI METABOLIT SEKUNDER MIKROBA ANTAGONIS UNTUK MENGENDALIKAN PENYAKIT DAN MENINGKATKAN HASIL TANAMAN JAGUNG DI KECAMATAN SUMBANG KABUPATEN BANYUMAS JAWA TENGAH
}

\author{
Loekas Soesanto $^{1 *}$, Abdul Manan ${ }^{1}$, dan Endang Mugiastuti ${ }^{1}$ \\ ${ }^{1}$ Program Studi Agroteknologi, Fakultas Pertanian, Universitas Jenderal Soedirman, \\ Jl. dr. Suparno, Purwokerto 53123 Jawa Tengah Indonesia \\ e-mail: lukassusanto26@gmail.com
}

\begin{abstract}
ABSTRAK
Kelompok tani "Mugi Rahayu" Desa Tambaksogra, Kecamatan Sumbang Kabupaten Banyumas Jawa Tengah merupakan kelompok tani yang banyak mengusahakan tanaman jagung. Permasalahan utama yang dihadapi dalam peningkatan produksinya adalah tingginya serangan penyakit tanaman. Sosialisasi pengelolaan penyakit jagung dengan menggunakan metabolit sekunder mikroba antagonis perlu dilakukan. Tujuan kegiatan adalah meningkatkan pengetahuan dan keterampilan petani tentang penyakit tanaman jagung serta tindakan pengelolaannya dengan metabolit sekunder. Permasalahan mitra diatasi dengan beberapa inovasi teknologi, yang dilakukan dengan metode transfer teknologi melalui pendidikan, pelatihan, demplot, dan pendampingan. Kegiatan sosialisasi mampu meningkatkan pengetahuan petani tentang jenis penyakit jagung, pengendaliannya, dan pengendalian yang ramah lingkungan sebesar 72,98\%. Sedangkan. kegiatan pelatihan perbanyakan dan metabolit sekunder mampu meningkatkan kemampuan petani masing-masing sebesar $48,57 \%$ dan 34,09\%. Pertumbuhan dan hasil jagung pada petak metabolit sekunder setara dibandingkan dengan petak petani dengan menggunakan pestisida kimia sintetik.
\end{abstract}

Kata kunci: metabolit sekunder; jagung; penyakit tanaman

\section{Pendahuluan}

Jagung merupakan salah satu komoditas yang sangat strategis, baik dalam sistem ketahanan pangan maupun perannnya sebagai penggerak perekonomian nasional. Selain sebagai sumber makan pokok kedua setelah beras, jagung juga memegang peran penting dalam pengembangan industri di Indonesia khususnya sebagai bahan baku industri pangan ataupun industri pakan ternak. Produksi jagung di Indonesia selama 3 tahun terakhir (tahun 2013-2015) selalu mengalami peningkatan, yaitu mencapai 18,51; 19,00; dan 19,83 juta ton/tahun (BPS, 2019). Namun demikian, peningkatan produksi tersebut belum mencukupi kebutuhan nasional akan jagung. Pada tahun 2016, pemerintah memutuskan untuk mengimpor jagung sebanyak 2,4 juta ton untuk kebutuhan pakan ternak (Kementerian Perindustrian, 2016).

Jagung ditanam secara meluas di seluruh wilayah Jawa Tengah, termasuk Kabupaten
Banyumas. Pada tahun 2015, luas panen di Kabupaten Banyumas meliputi 4.033 ha dengan produksi mencapai 21.340 ton (BPS Jateng, 2017). Setiap tahunnya, Kecamatan Sumbang merupakan kecamatan di Kabupaten Banyumas yang mempunyai luas pertanaman jagung tertinggi, dan pada tahun 2015 mencapai 1.738 ha dengan produksi 9.194,02 ton. (Pemda Banyumas, 2016).

Desa Tambaksogra Kecamatan Sumbang sangat potensial untuk pengembangan bidang pertanian tanaman pangan, termasuk tanaman jagung dilihat dari kondisi sumberdaya alam dan sumberdaya manusianya serta pasar yang tersedia. Salah satu kelompok tani yang membudidayakan jagung di Desa Tambaksogra adalah Kelompok tani "Mugi Rahayu".

Petani jagung anggota kelompok tani Mugi Rahayu, sudah menerapkan cara budidaya jagung dengan baik dan benar.Namun demikian, 
ketergantunganpetani pada penggunaan pestisida kimiawi sintetik untuk mengendalikan penyakit tanaman masih sangat tinggi. Tingginya harga pestisida menyebabkan biaya produksi menjadi meningkat, sedangkan harga jual hasil tanaman relatif tetap sehingga pendapatan anggota kelompok tani menjadi berkurang. Disamping itu, penggunaan pestisida kimia sintetik yang tidak bijaksana menyebabkan terjadinya pencemaran lingkungan, kematian musuh alami, serta menimbulkan resistensi hama dan penyakit dan yang lebih membahayakan lagi adalah tingginya residu pestisida pada produk pertanian yang dihasilkan.

Permasalahan tersebut, dapat diatasi dengan melakukan perubahan teknik budidaya tanaman, terutama pengelolaan penyakit yang ramah lingkungan. Bila permasalahan tersebut dapat diatasi, maka akan terjadi peningkatan kuantitas dan kualitas produksijagung dari Desa Tambaksogra, sehingga pendapatan petani meningkat.

Adapun tujuan dari kegiatan adalah:

1. Meningkatkan pengetahuan petani tentang jenis penyakit pada tanaman jagung dan pengendaliannya yang efektif, efisien, dan ramah lingkungan.

2. Meningkatkan ketrampilan petani tentang pengendalian penyakit tanaman jagung yang efektif, efisien, dan ramah lingkungan.

3. Meningkatkan kuantitas dan kualitas produksi tanaman jagung.

4. Meningkatkan pendapatan petani tanaman jagungmelalui peningkatan efisiensi usaha tani.

Manfaat yang diharapkan dari kegiatan ini adalah: 1). motivasi untuk pengembangan usaha meningkat, 2) terjadinya efisiensi usaha yang signifikan, 3) penyerapan tenaga kerja meningkat.

\section{Permasalahan mitra}

Permasalahan utama yang dihadapi mitra adalah :

1. Penyakit Bulai yang disebabkan oleh jamur Peronosclerospora maydis merupakan penghambat utama produksi jagung dari kelompok tani tersebut (Gambar 1). Selama ini penyakit bulai selalu menjadi masalah utama dalam budidaya jagung. Apabila jamur ini menginfeksi tanaman muda dari varietas rentan dapat mengakibatkan kerusakan tanaman sampai $100 \%$. Penyebaran penyakit bulai terjadi sangat cepat, karena konidia menyebar melalui udara dan oosporanya dapat tersimpan lama di tanah serta dapat menular melalui benih, terutama pada benih yang masih segar dan berkadar air tinggi. Pada Kelompok Tani Mugi Rahayu kehilangan hasil akibat penyakit ini rata-rata mencapai 30-40 \%. Namun pada musim hujan, beberapa petani mengalami penurunan produksi sampai $60 \%$.

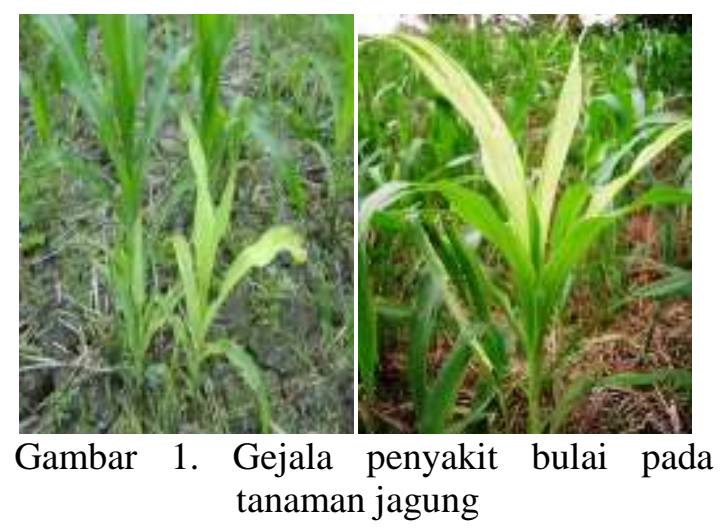

2. Penyakit karat daun (Puccinia maydis) dan hawar pelepah (Rhizoctonia solani)(Gambar 2). Penyakit tersebut menyebabkan keringnya daun dan batang. Penyakit mampu berkembang dan menyebar dengan cepat hingga menimbulkan kehilangan hasil yang cukup signifikan, terutama jika infeksinya terjadi sebelum bunga betina keluar. Selama 2 tahun terakhir, penyakit ini dapat menurunkan produksi sampai $20 \%$. Pengendalian yang efektif yang ramah lingkungan dengan menggunakan metabolit sekunder belum diketahui petani mitra. 


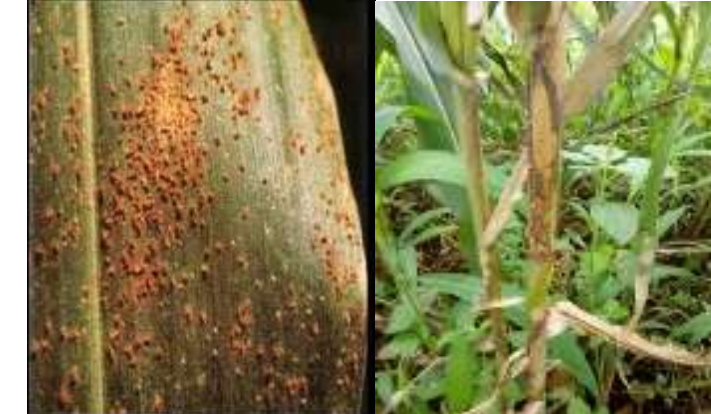

Gambar 2. Gejala penyakit karat daun dan hawar pelepah pada tanaman jagung.

3. Upaya pengendalian penyakit yang dilakukan selama ini lebih menekankan kepada penggunaan fungisida kimia sintetik. Namun demikian, hasilnya kurang memuaskan. Disamping itu, konsekuensi dampak negatif yang diakibatkannya cukup besar. Pemanfaatan metabolik sekunder sebagai bio pestisida yang efektif dan ramah lingkungan belum diadopsi petani. Bertitik tolak dari uraian di atas maka dilakukan sosialisasi perbaikan dalam budidaya tanaman jagung dengan memanfaatkan metabolit sekunder Trichoderma sp. dan $P$. fluorescens untuk mengendalikan Penyakit Utama serta Meningkatkan Hasil Tanaman Jagung di Desa Tambaksogra Kecamatan Sumbang Kabupaten Banyumas.

\section{Metode}

Untuk mengatasi permasalahan mitra beberapa solusi teknologi yang ditawarkan dilakukan dengan metode transfer teknologi melalui pendidikan, pelatihan, pendampingan dan demplot. Metode pendidikan melalui ceramah dan diskusi dilakukan sebagai media alih informasi yang bersifat interaktif dan berlangsung dua arah. Metode ini merupakan inisiasi program dengan harapan, petani mempunyai pengetahuan dasar yang baik tentang pengetahuan jenis penyakit jagung dan upaya pengendaliannya yang efektif, efisien dan ramah lingkungan. Penerapan program dilanjutkan dengan peningkatan ketrampilan petani melalui metode demplot. Demplot budidaya tanaman jagung dikelola dengan teknik pengendalian penyakit yang efektif, efisien, dan ramah lingkungan dengan menggunakan metabolit sekunder $T$. harzianum dan $P$. flourescens. Diharapkan adopsi teknologi tersebut selanjutnya berkembang dari pusat percontohan ke daerah lain, baik yang berada di sekitar percontohan maupun wilayah sentra tanaman jagung di desa lainnya. Kelompok tani tanaman jagung yang dipilih dan dibina secara intensif melalui pendampingan, diharapkan juga mampu sebagai kader penggerak dalam pengembangan budidaya jagung secara baik.

\section{Hasil dan Pembahasan}

a. Sosialisasi potensi metabolit sekunder untuk mengendalikan penyakit tanaman jagung

Sosialisasi dilakukan dengan metode ceramah di rumah ketua kelompok tani (gambar3). Pada kesempatan tersebut diinformasikan sekilas tentang metabolit sekunder mikroba antagonis dan kemampuan teknologi tersebut dalam mengendalikan beberapa patogen penyebab penyakit tanaman pada berbagai jenis tanaman budidaya, termasuk penyakit jagung. Disamping itu, disampaikan pula bukti metabolit sekunder mampu menghasilkan hormon pertumbuhan (IAA) dan membantu dekomposisi bahan organik menjadi nutrisi tanaman yang pada akhirnya dapat meningkatkan produksi tanaman.

Hasil sosialisasi menunjukkan terjadi peningkatan pengetahuan peserta sebesar $52,17-76,23 \%$.

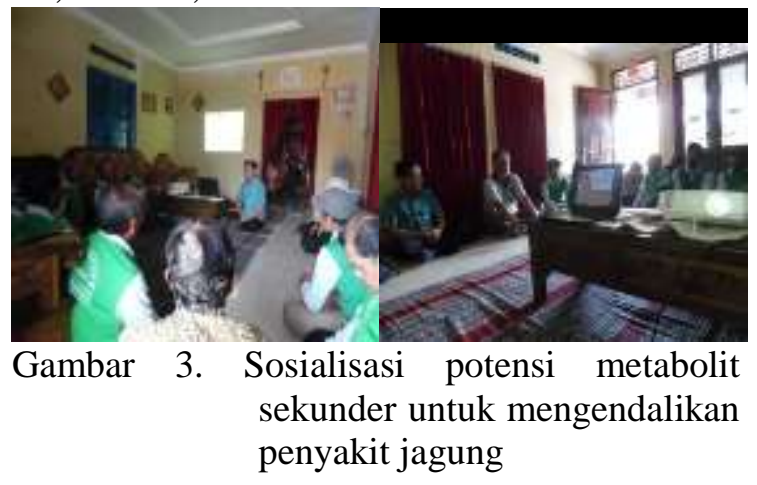

\section{b. Pelatihan pembuatan metabolit sekunder Trichoderma dan $P$. flourescens}

Pelatihan pembuatan metabolit sekunder merupakan kelanjutan dari kegiatan sosialisasi yang diadakan 
sebelumnya. Pelatihan juga dilakukan di rumah ketua kelompok tani (gambar 4).

Pembuatan metabolit sekunder dilakukan dengan menggunakan bahan yang ada di sekitar petani yaitu: air kelapa, air cucian beras dan kaldu keong mas. Dalam pelatihan ini petani peserta dibatkan secara langsung dalam kegiatan dengan harapan setelah pelatihan petani peserta secara mandiri mampu menerapkan hasil pelatihannya. Hasil evaluasi menunjukkan bahwa terjadi peningkatan ketrampilan petani peserta tentang pembuatan metabolit sekunder sebesar 88,12-92,13 persen.

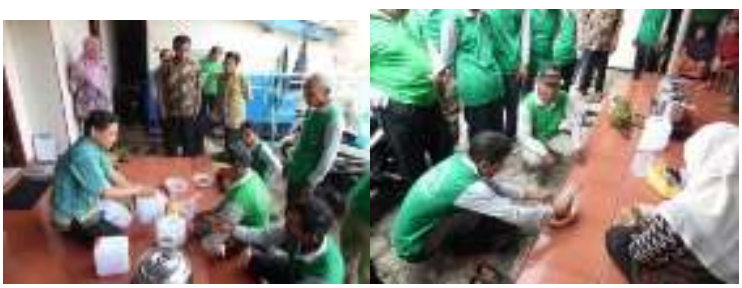

Gambar 4. Pelatihan pembuatan metabolit sekunder

\section{c. Demplot}

Pembuatan demplot bertujuan agar petani dapat lebih memahami dan menghayati pelatihan yang telah diberikan, serta dapat mengambil keputusan terhadap langkah budidaya tanaman jagung pada lahan pertanian masing-masing. Demplot teknologi budidaya tanaman jagung ramah lingkungan menerapkan penggunaan metabolit sekunder dilaksanakan pada lahan kelompok tani, dan diikuti oleh anggota kelompok tani mitra dan perwakilan dari kelompok tani lain, dan PPL setempat.

Lahan Tanaman jagung yang digunakan sebagai lahan demplot dbersihkan dari gulma, kemudian dibagi menjadi dua bagian. Satu bagian ditanami jagung dengan menggunakan paket teknologi metabolit sekunder sedangkan satu bagian lainnya ditanami jagung dengan menggunakan teknologi petani yaitu dengan menggunakan pestisida kimia sintetik gambar 5). Metabolit sekunder yang digunakan dalam demplot merupakan hasil pelatihan sebelumnya. Pertumbuhan tanaman jagung pada kedua petak demplot diamati bersama dengan petani mitra. Tinggi tanaman, panjang daun, dan hasil tanaman jagung disajikan pada Tabel 1 .

Tabel 1. Pertumbuhan tanaman dan hasil jagung pada petak teknologi dan petak petani

\begin{tabular}{lcc}
\hline \multicolumn{1}{c}{ Parameter } & $\begin{array}{c}\text { Petak } \\
\text { petani }\end{array}$ & $\begin{array}{c}\text { Petak } \\
\text { teknologi }\end{array}$ \\
\hline Tinggi tanaman (cm) & $202,25 \mathrm{a}$ & $\begin{array}{c}203,65 \\
\mathrm{a}\end{array}$ \\
Panjang daun (cm) & $78,46 \mathrm{a}$ & 77,26 \\
& & $\mathrm{a}$ \\
Intensitas karat daun (\%) & $20,52 \mathrm{a}$ & 19,87 \\
Intensitas hawar pelepah & $15,21 \mathrm{a}$ & $\mathrm{a}$ \\
$(\%)$ & & 16,21 \\
& & $\mathrm{a}$ \\
Hasil (t/ha) & $4,35 \mathrm{a}$ & $4,41 \mathrm{a}$ \\
\hline
\end{tabular}

Berdasarkan hasil pengamatan tersebut, nampak bahwa pertumbuhan dan hasil pada tanaman jagung yang dibudidayakan menggunakan paket teknologi metabolit sekunder tidak berbeda nyata dibandingkan dengan pertumbuhan jagung pada petak petani dengan menggunakan pestisida kimia sintetik. Selain pertumbuhan tanaman, diamati pula intensitas penyakit yang menyerang tanaman jagung. Berdasarkan pengamatan, intensitas penyakit karat daun dan hawar pelepah daun pada petak petani berturut-turut mencapai $20,25 \%$ dan 15,21 $\%$, sedangkan pada petak teknologi $19,87 \%$ dan 16,21 \%. Hasil analisis statistik menunjukkan bahwa intensitas penyakit pada petak teknologi juga tidak berbeda nyata dibandingkan dengan petak petani. Hal ini membuktikan kepada petani mitra bahwa teknologi metabolit sekunder dapat mensubtitusi penggunaan pestisida kimia sintetik pada budidaya tanaman jagung. Disamping itu, penggunaan metabolit sekunder mempunyai kelebihan lainnya yaitu: ramah lingkungan, murah, dan mudah dilakukan secara mandiri oleh petani.

Hasil demplot ini juga selaras dengan hasil penelitian yang sudah dilakukan. Metabolit sekunder yang dihasilkan Trichoderma sp. dan P. Fluorescens diketahui mampu menekan patogen melalui berbagai mekanisme di antaranya persaingan ruang atau nutrisi dan menghasilkan senyawa antibiotika ataupun senyawa toksin lain 
Abditani : Jurnal Pengabdian Masyarakat 2 (2) 66-66

e-ISSN : 2622-4690

p-ISSN : 2622-4682

(Soesanto, 2013). Selain itu, mikrobamikroba tersebut mampu mengimbas ketahanan tanaman.Trichoderma spp. mampu menghasilkan berbagai metabolit sekunder seperti antibiotika, beberapa jenis enzim, senyawa metabolit beracun maupun organisme pelarut mineral dan dekomposer. Hasil pengujian in vitro menunjukkan, Trichoderma sp. mampu menghambat pertumbuhan jamur patogen Fusarium, $S$. Colletotrichum, Phytophthora, dan Sclerotium (Soesanto et al., 2013). Hasil uji in planta, Trichoderma sp. isolat jahe mampu menekan penyakit bulai pada jagung manis sebesar 60,55 \%. Trichoderma sp.juga mampu menekan perkembangan penyakit busuk pangkal batang dan bercak daun kacang tanah, penyakit puru akar tanaman tomat, penyakit layu Fusarium lada, antraknosa cabai, layu bakteri tomat, penyakit busuk rimpang pada jahe, penyakit hawar pelepah daun dan virus pada cabai (Amalia et al., 2004; Maqqon et al., 2006, Prabowo et al., 2006, Santoso et al., 2007, Soesanto et al, 2005, 2014, 2015; Wardhana et al., 2009).

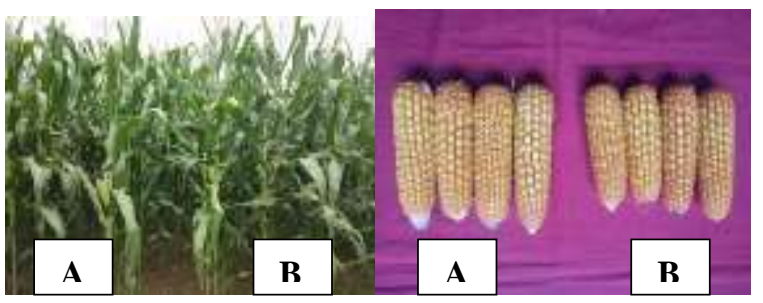

Gambar 5.Demplot aplikasi teknologi metabolit sekunder pada budidaya jagung: A. Petak teknologi, B. Petak petani

\section{d. Pendampingan}

Kegiatan pendampingan dilakukan dengan 2 cara. Pertama kegiatan pendampingan dilakukan melalui kegiatan pertemuan rutin kelompok tani, dimana anggota petani dapat berdiskusi dan dengan tim pengabdi, tentang budidaya jagung dan pengelolaan penyakit yang ramah lingkungan. Disamping itu, pendampingan juga dilakukan langsung di lapangan. Pada kegiatan di lapangan, tim mendampingi secara langsung, pembuatan metabolit sekunder ramah lingkungan dari mulai pemilihan bahan yang murah dan mudah dijumpai di sekitar petani, alat yang mudah dijumpai dan tersedia serta kiat dan kendala dalam proses pembuatannya. Kemudian pendampingan diteruskan sampai kepada cara aplikasi metabolit sekunder pada budidaya tanaman jagung. Dari mulai cara perendaman benih jagung yang akan ditanam sampai cara aplikasi metabolit sekunder di lapangan. Demikian juga alat yang digunakan, konsentrasi serta saat aplikasi yang disesuaikan dengan fenologi tanaman. Cara penyimpanan dan lama simpan yang disarankan juga diinformasikan ke petani mitra.

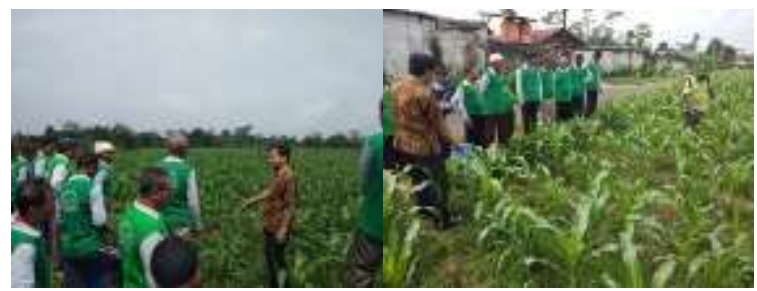

Gambar 6. Pendampingan petani di lapangan

\section{e. Evaluasi dan diseminasi}

Setelah kegiatan demplot dilaksanakan selanjutnya kegiatan berikutnya adalah evaluasi akhir dan diseminasi kegiatan. Evaluasi dilakukan berdasarkan analisis dan interpretasi data pengamatan di lapangan, evaluasi dilakukan bersama antara Tim Pengabdi dan anggota kelompok tani. Berdasarkan hasil evaluasi menunjukkan bahwa penggunaan metabolit sekunder kedua mikroba antagonis dapat mengatasi masalah yang dihadapi petani. Hal ini semakin membuka wawasan petani akan manfaat teknologi metabolit sekunder.

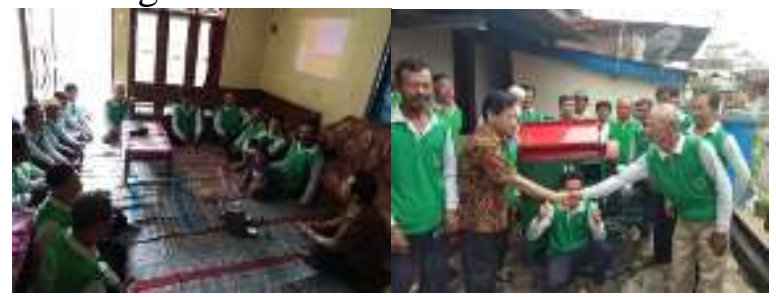

Gambar 7.Diseminasi hasil kegiatan dan penyerahan bantuan alat kepada petani mitra 
Diseminasi kegiatan selanjutnya dilakukan kepada kelompok tani jagung yang lain di desa yang sama serta dengan mengundang kelompok tani lainnya. Kegiatan dilakukan dengan penyuluhan dan praktik pembuatan metabolit sekunder mikroba antagonis yang mudah, murah, dan praktis. Peserta kegiatan sangat antusias dan aktif dengan banyaknya pertanyaan dan kegiatan praktik yang langsung dilakukan. Diseminasi juga dilakukan dalam forum ilmiah tahunan yang diselenggarakan Lembaga Penelitian dan Pengabdian kepada Masyarakat Unsoed dan jurnal pengabdian kepada masyarakat.

\section{Kesimpulan}

1. Pengetahuan dan ketrampilan petani peserta tentang metabolit sekunder Trichoderma dan Peseudomonas flourescens dalam mengendalikan penyakit tanaman meningkat.

2. Pertumbuhan dan hasil tanaman serta intensitas serangan penyakit tanaman jagung pada petak aplikasi metabolit sekunder Trichoderma dan Peseudomonas flourescens setara bila dibandingkan dengan petak apikasi pestisida kimia sinteik.

3. Metabolit sekunder Trichoderma dan Peseudomonas flourescens dapat mensubtitusi penggunaan pestisida kimia sintetik pada budidaya tanaman jagung.

\section{Ucapan Terima Kasih}

Terima kasih kepada LPPM Unsoed, atas dukungan pendanaannya melalui Hibah PKM berbasis riset, juga kepada semua anggota Kelompok Tani Ngudi Luhur Kecamatan Sumbang, Kabupaten Banyumas Jawaa tangah atas kerjasamanya yang terjalin baik

\section{Daftar Pustaka}

Amalia, R., H.A. Djatmiko, dan L. Soesanto. (2004). Potensi beberapa antagonis dalam menekan Fusarium oxysporum Schlecht. f.sp. zingiberi Trujillo pada tanaman jahe. Hal. 301-312. Dalam: L. Soesanto (Ed.), Prosiding Simposium Nasional I tentang Fusarium, Purwokerto, 26-27 Agustus 2004.
BPS, 2019. Produksi Jagung Menurut Provinsi (ton) Tahun 2015, http://www.bps. go.id/site/result/Tab., 27Agusutus 2019.

BPS Jateng, 2017. Luas Panen dan Produksi dan Produktivitas Jagung menurut Kabupaten/kota di Jawa Tengah tahun 2015, http://jateng.bps.go.id/linktabel statis/view/id/1191, diakses 25 November 2017.

Kementerian perindustrian. 2016, RI impor $\begin{array}{llll}\text { jagung } & 2,4 & \text { Juta }\end{array}$ http://www.kemenperin.go.id/artikel/1389 2/2016,-RI-Impor-Jagung-2,4-Juta-Ton diakses tgl 26 Juni 2016.

Maqqon, M., Kustantinah, dan L. Soesanto. 2006. Penekanan hayati penyakit layu Fusarium pada tanaman cabai merah. Agrosains 8(1):50-56.

Pemda Banyumas, 2016. Banyumas dalam Angka. Pemerintah Kabupaten Banyumas.

Prabowo, A.K.E., N. Prihatiningsih, dan L. Soesanto. 2006. Potensi Trichoderma harzianum dalam mengendalikan sembilan isolat Fusarium oxysporum Schlecht. f.sp. zingiberi Trujillo pada kencur. Jurnal Ilmu-Ilmu Pertanian Indonesia 8(2):77681.

Santoso, S.E., L. Soesanto, dan T.A.D. Haryanto. 2007. Penekanan hayati penyakit moler pada bawang merah dengan Trichoderma harzianum, Trichoderma koningii, dan Pseudomonas fluorescens P60. Jurnal HPT Tropika 7(1):53-61.

Soesanto, L., Soedharmono, N. Prihatiningsih, A. Manan, E. Iriani, dan J. Pramono. 2005. Potensi agensia hayati dan nabati dalam mengendalikan penyakit busuk rimpang jahe. Jurnal HPT Tropika 5(1):50-57.

Soesanto, L, E. Mugiastuti, R.F. Rahayuniati dan R.S. Dewi. 2013. Perakitan Biopestisida Trichoderma sebagai Agensia Hayati Penyakit Tanaman untuk Meningkatkan Produksi Tanaman, Laporan Penelitian Hibah Kompetensi Tahun I. Universitas Jenderal Soedirman, Purwokerto.

Soesanto, L, E. Mugiastuti dan B. Prakoso. 2014. Perakitan Biopestisida Trichoderma sebagai Agensia Hayati Penyakit Tanaman untuk Meningkatkan Produksi Tanaman, Laporan Penelitian Hibah Kompetensi Tahun II. Universitas Jenderal Soedirman, Purwokerto. 
e-ISSN : 2622-4690

Abditani : Jurnal Pengabdian Masyarakat 2 (2) 66-66

p-ISSN : 2622-4682

Soesanto, L, A. Suyanto, dan E. Mugiastuti, 2015. Perakitan Biopestisida Trichoderma sebagai Agensia Hayati Penyakit Tanaman untuk Meningkatkan Produksi Tanaman, Laporan Penelitian Hibah Kompetensi
Tahun III. Universitas Jenderal Soedirman, Purwokerto.

Wardhana, D.W., L. Soesanto, dan D.S. Utami. 2009. Penekanan hayati penyakit layu fusarium pada subang gladiol. Jurnal Hortikultura 19(2):304-311. 